\title{
Attenuation of diabetic hepatopathy in alloxan-induced diabetic mice by methanolic flower extract of Phlogacanthus thyrsiflorus Nees
}

\author{
Jutishna Bora, Plabita Sahariah, Abani Kumar Patar, Donkupar Syiem, Surya Bhan*
}

Department of Biochemistry, North Eastern Hill University, Shillong-793022, Meghalaya, India.

\begin{tabular}{l}
\hline ARTICLE INFO \\
\hline Article history: \\
Received on: 09/03/2018 \\
Accepted on: 07/06/2018 \\
Available online: $30 / 07 / 2018$ \\
\\
\hline Key words: \\
Phlogacanthus thyrsiflorus, \\
methanolic flower extract, \\
alloxan, antioxidant.
\end{tabular}

\begin{abstract}
The present investigation is aimed to determine the effect of methanolic flower extract (MFE) of phlogacanthus thyrsiflorus on hyperglycemia, hyperlipidemia and oxidative stress in alloxan-induced diabetic mice. Diabetic mice prepared with alloxan $(150 \mathrm{mg} / \mathrm{kg})$ body weight (bw) were treated with effective different doses $(150-550 \mathrm{mg} / \mathrm{kg} \mathrm{bw})$ of MFE. Intraperitoneal glucose tolerance test (IPGTT) was performed. Activities of marker enzymes and lipid profile were determined. Similarly, superoxide dismutase (SOD) - cytosolic CuZn-SOD and mitochondrial Mn-SOD, catalase (CAT) and glutathione reductase (GR) activities were examined. After treatment with MFE, $250 \mathrm{mg} / \mathrm{kg}$ bw dose was found to be effective in significantly reducing fasting blood glucose (FBG) level. In IPGTT, there was a significant reduction of FBG level in treated groups. The MFE also exhibited a significant hypolipidemic effect as evident from a decrease in total cholesterol, triglycerides, low-density lipoproteins-cholesterol (LDL-C), very low-density lipoproteins-cholesterol (VLDL-C) and increased high-density lipoproteins-cholesterol (HDL-C) level. Activities of marker enzymes were significantly decreased in treated diabetic groups. However, the activities of antioxidant enzymes were significantly increased in treated diabetic groups. The histopathological studies of the liver tissue in MFE treated diabetic mice revealed almost normal appearance. This study supports the traditional proclamations and use of flowers of Phlogacanthus thyrsiflorus for the management of diabetes.
\end{abstract}

\section{INTRODUCTION}

Diabetes, termed as diabetes mellitus, is a major epidemic of this century (Shaw et al., 2010). The incidence of diabetes is rapidly increasing with estimates that the number will almost be doubled by 2030 (Wild et al., 2004). Diabetes is clinically characterized by hyperglycemia due to its chronic and/or relative insulin insufficiency (Mathis et al., 2001). Diabetes mellitus is also associated with insulin resistance, hyperlipidemia, hypertension (Taylor et al., 1994). Moreover, it is linked with increased free radicals leading to compromise defense system (Saxena et al., 1993). The management of diabetes mellitus is considered to be a global problem and successful treatment has yet to be discovered. In India, indigenous remedies have been always used in the treatment of diabetes mellitus since the sixth century (Kashikar and Tejaswita, 2011). Phlogacanthus thyrsiflorus is a shrub from a

${ }^{*}$ Corresponding Author

Dr. Surya Bhan, Assistant Professor, Department of Biochemistry, North

Eastern Hill University, Shillong, 793022.

E-mail:sry_bhan@yahoo.co.in family of Acanthaceae, which has several common names such as titaaphul, chuhai, dieng-soh etc. Phlogacanthus thyrsiflorus is one of a common herbal plant used by local people of Assam to manage diabetes. The generation of free radicals has been implicated in the causation of several diseases such as Rheumatoid arthritis, Cancer, Diabetes etc., and compound that can scavenge free radicals present in Phlogacanthus thyrsiflorus have great potential in ameliorating these disease processes. Phlogacanthus thyrsiflorus has prominent free radical scavenging property so it may prove as a very good medicinal herb (Jaiswal, 2010). Considering the above medicinal properties of Phlogacanthus thyrsiflorus, it is of interest to undertake a systematic study of such plant. Thus present study was aimed to investigate the antihyperglycemic, antihyperlipidemic and antioxidative properties of methanolic flower extract (MFE) from Phlogacanthus thyrsiflorus.

\section{MATERIALS AND METHODS}

\section{Chemicals}

Alloxan, metformin, and pyrogallol were purchased 
from Sigma-Aldrich Co. (St. Louis, MO, USA.). Glibenclamide was procured from Emcure Pharmaceuticals Ltd. (Pune, India). Insulin was procured from Gland Pharma Ltd. (Hyderabad, India). Total cholesterol, triglyceride, HDL and SGOT, SGPT kits were purchased from Coral Biosystems (Goa, India). The other chemicals used were of analytical grade procured from Merck Co. (Mumbai, India) and Sisco Research laboratory.

\section{Plant material}

Flowers of Phlogacanthus thyrsiflorus were collected during January from Assam, India (Voucher No: 12055). The specimen was submitted and authenticated by Dr. P.B. Gurung Curator herbarium, Department of Botany, NEHU, Shillong, Meghalaya.

\section{Methanolic extracts preparation}

The collected flowers were separated, weighed, washed and subjected to the shade-dried. It was then powered, homogenized and repeatedly extracted with $10 \mathrm{X}$ volume of aqueous-methanol solution (1:4) (Harborne, 1998). The dried mass was stored at $-20^{\circ} \mathrm{C}$ and used for further studies.

\section{Phytochemical screening}

The MFE was subjected to qualitative phytochemical analysis for alkaloids, flavonoids, tannins, saponins, and phenols as per the standard methods (Wali et al., 2012).

\section{Test animals}

Adult healthy Swiss male albino mice (Balb/C strain), 20-30 g in weight were used for all the studies. The procedure of all the experiments was reviewed and carried out in accordance with the Institutional Ethics Committee guidelines (Animal models), North-Eastern Hill University, Shillong, Meghalaya, 04-12-2014. Mice were housed under controlled temperature i.e. at $22^{\circ} \mathrm{C}$ on a $12 \mathrm{hr}$ light/dark cycle and were fed with mice feed which were obtained from the laboratory of Amrut, Pune, India and water ad libitum.

\section{Acute toxicity study}

Acute toxicity test i.e. lethal dose 50 (LD50) for the MFE was carried out as per Organisation for Economic Cooperation and Development Guidelines 425 (OECD) guidelines. Six different test groups were considered containing six female mice in each group and increasing doses from $200 \mathrm{mg} / \mathrm{kg}$ body weight (bw) to $2000 \mathrm{mg} / \mathrm{kg}$ bw were administered intraperitoneally following the limit test procedure. Animals in all groups were observed till $24 \mathrm{hr}$. LD50 value was determined by the Arithmetic method described by Ghosh (Ghosh, 2015).

$$
\begin{gathered}
\mathrm{LD} 50=\mathrm{LD} 100-(\text { Product } \mathrm{a} \times \mathrm{b} / \text { number of animals in } \\
\text { each group }),
\end{gathered}
$$

where $\mathrm{a}=$ Dose difference (Dose in given interval - Dose in upper interval) and $b=$ Mean mortality (No. of dead mice in given interval + No. of dead mice in upper interval) $/ 2$.

\section{Induction of diabetes mellitus in test animals}

Alloxan monohydrate $(150 \mathrm{mg} / \mathrm{kg}$ bw) prepared in citrate buffer $(0.1 \mathrm{M}, \mathrm{pH} 4.5)$ was administered intraperitoneally to overnight fasted test albino mice for induction of diabetes
(Syiem et al., 2002). After alloxan injection, mice had free access to food and water. The fasting blood glucose (FBG) levels were checked after $72 \mathrm{hr}$ of alloxan injection and the mice showing blood glucose level more than $200 \mathrm{mg} / \mathrm{dl}$ were selected and used for further tests.

\section{Antihyperglycemic study}

Alloxan induced diabetic mice were divided into one control and six test groups comprising of six mice in each group. Control group consisting of diabetic mice administered with only distilled water and diabetic mice in test groups were administered with increasing doses $(150 \mathrm{mg} / \mathrm{kg} \mathrm{bw}-550 \mathrm{mg} / \mathrm{kg}$ bw) of MFE intraperitoneally to carry out the antihyperglycemic study. Doses were injected intraperitoneally every alternate day for 21 days (d) and FBG levels were monitored on $7 \mathrm{~d}, 14 \mathrm{~d}$ and $21 \mathrm{~d}$ respectively (Syiem and Khup, 2006).

\section{Intraperitoneal glucose tolerance test (IPGTT)}

Alloxan-induced diabetic mice were divided into one control (diabetic mice) and four test groups comprising of six mice in each group to perform intraperitoneal glucose tolerance test (IPGTT) test. The MFE (250 mg/kg bw), the drugs- metformin $(200 \mathrm{mg} / \mathrm{kg} \mathrm{bw})$ and glibenclamide $(10 \mathrm{mg} / \mathrm{kg} \mathrm{bw})$ dissolved in $10 \mathrm{X}$ volume of aqueous-methanol solution (1:4) and the hormone insulin $(10 \mathrm{U} / \mathrm{kg}$ bw) were administered to the test groups intraperitoneally prior to the glucose load ( $2 \mathrm{~g} / \mathrm{kg} \mathrm{bw}$ ) (Syiem et al., 2002). The reason behind selecting three standard drugs in this study only to determine the possible mechanism of action of MFE since each drug has a different mechanism of action to lower the blood glucose level. The FBG levels were monitored before the administration and subsequently at $0.5 \mathrm{hr}, 1 \mathrm{hr}, 2 \mathrm{hr}$ and $4 \mathrm{hr}$ respectively after the glucose load.

\section{Biochemical analysis}

\section{Serum and liver parameters}

Four different test groups comprising of six mice in each group were considered and doses were injected intraperitoneally every alternate day for $21 \mathrm{~d}$.

Normal untreated group: Normal mice administered only with distilled water.

Diabetic untreated group: Diabetic mice administered only with distilled water.

Ascorbic acid treated group: $50 \mathrm{mg} / \mathrm{kg}$ bw dose of ascorbic acid administered to diabetic mice.

MFE treated group: $250 \mathrm{mg} / \mathrm{kg}$ bw dose of MFE administered to diabetic mice.

Blood was collected from retro-orbital plexus of the animals and serum was isolated from all the blood samples for lipid profile tests and for hepatic marker enzyme assays. In lipid profile test, total cholesterol, high-density lipoprotein-cholesterol (HDL-C), and triglyceride levels were measured using CHOD/ PAP kit method, PEG/CHOD-PAP kit method and GPO/PAP kit method respectively. The low-density lipoprotein-cholesterol (LDL-C) and very high-density lipoprotein-cholesterol (VLDLC) levels were calculated according to the formula (Friedewald et al., 1972) mentioned below

$$
\begin{gathered}
\text { VLDL-C }=\text { Triglycerides } / 5, \\
\text { LDL-C }=\text { Total Cholesterol }-(\text { HDL-C }+ \text { VLDL-C }) .
\end{gathered}
$$


Serum hepatic marker enzyme, serum glutamate oxalate - transaminase (SGOT) and serum glutamate pyruvate transaminase (SGPT) activities were determined using the Coral diagnostic kit (Coral Clinical Systems, Goa, India) and mean activities were expressed in terms of units/liter (U/L).

\section{Liver antioxidant enzyme assays}

Swiss albino mice were divided into four groups comprising of six mice in each group for the study. Doses were administered intraperitoneally on alternate days for a total period of $21 \mathrm{~d}$.

Normal untreated group: Normal mice administered only with distilled water.

Diabetic untreated group: Diabetic mice administered only with distilled water.

Ascorbic acid treated group: Ascorbic acid (50 mg/kg bw) treated diabetic mice.

MFE treated group: MFE (250 mg/kg bw) treated diabetic mice.

\section{Preparation of homogenate}

Liver tissue was excised from all the experimental groups by decapitation after $21 \mathrm{~d}$. Tissue were homogenized to make $10 \%(\mathrm{w} / \mathrm{v})$ homogenates in ice-cold $10 \mathrm{mM}$ HEPES buffer, pH 7.4 containing $0.2 \mathrm{M}$ mannitol, $50 \mathrm{mM}$ sucrose and $1 \mathrm{mM}$ EDTA. Nuclei and cell debris were sedimented by centrifuging tissue homogenate for $10 \mathrm{mins}$ at $4^{\circ} \mathrm{C}$ at $1000 \mathrm{~g}$. The supernatant collected was again centrifuged for 10 mins at $4^{\circ} \mathrm{C}$ at 7500 g. Mitochondrial fraction was obtained with the resulting mitochondrial pellet from above procedure being washed gently by suspending in homogenate buffer and then resedimented at $7500 \mathrm{~g}$ for $10 \mathrm{mins}$ at $4^{\circ} \mathrm{C}$. Cytosolic fraction was obtained by centrifuging the post-mitochondrial supernatant further for 10 mins at $4^{\circ} \mathrm{C}$ at $1500 \mathrm{~g}$.

The protein concentration of cytosolic and mitochondrial fraction was determined by Bradford method (Bradford, 1976) using bovine serum albumin as a standard.

Superoxide dismutase (SOD) both $\mathrm{Mn}-\mathrm{SOD}$ and $\mathrm{Cu}$ / Zn-SOD activity was determined with slight modifications according to the method of Marklund and Marklund (Marklund and Marklund, 1974). The Catalase (CAT) activity was estimated by the method of Aebi (Aebi, 1984). The glutathione reductase (GR) activity was assayed by the method of Carlberg and Mannervik (Carlberg and Mannervik, 1985).

\section{Histopathological examination}

Liver of normal, diabetic and diabetic mice treated with ascorbic acid and MFE were excised after 21 days by sacrificing the mice by cervical dislocation and the histological study was carried out using hematoxylin-eosin (HE) staining techniques (Kiernan, 1999).

\section{Statistical analysis}

Results of all the experiments are expressed as mean \pm SEM for each group consisting of six mice in each group. Data were analyzed using one-way ANOVA followed by tukey's post hoc test which was performed to compare the differences between all the experimental groups using statistical IBM SPSS software package for Windows version 19.0. Statistical significance was put as $\mathrm{p}<0.05$.

\section{RESULTS}

\section{Qualitative phytochemical analysis}

Phenols, flavonoids, and tannins were strongly present in the MFE whereas alkaloids and saponins were slightly present.

\section{Acute toxicity studies}

LD50 value of the extract was $1867 \mathrm{mg} / \mathrm{kg}$ bw which indicates that MFE is safe and is not toxic to mice.

\section{Antihyperglycemic study}

The MFE administered to diabetic mice elicited marked and prolonged antihyperglycemic action in time and dosedependent manner (figure 1). The antihyperglycemic effect was found to be more pronounced at the $21 \mathrm{st} \mathrm{d}$ for all the doses used. There was a minimal reduction $(18.3 \%)$ of FBG level at the dose of $150 \mathrm{mg} / \mathrm{kg}$ bw on $21 \mathrm{~d}$. However, a significant reduction $(23 \%)$ was observed at $250 \mathrm{mg} / \mathrm{kg}$ bw on $7 \mathrm{~d},(34 \%)$ on $14 \mathrm{~d}$ and $(45.9 \%)$ on $21 \mathrm{~d}$ from that of the control group. However, administration of MFE at the higher doses resulted in marked antihyperglycemic effect. At $350 \mathrm{mg} / \mathrm{kg}$ bw, the FBG levels were $(28.7 \%)$ on 7 $\mathrm{d},(46.6 \%)$ on $14 \mathrm{~d},(58.8 \%)$ on $21 \mathrm{~d}$ when compared with the diabetic control group in the study. At the doses of $450 \mathrm{mg} / \mathrm{kg}$, bw and $550 \mathrm{mg} / \mathrm{kg}$ bw showed a drastic reduction of FBG level. At $450 \mathrm{mg} / \mathrm{kg}$ bw, the FBG levels were $55 \%$ on $7 \mathrm{~d}, 63.2 \%$ on $14 \mathrm{~d}$, $64.6 \%$ on $21 \mathrm{~d}$ while at $550 \mathrm{mg} / \mathrm{kg}$ bw the FBG levels were $67 \%$ on $7 \mathrm{~d}, 74 \%$ on $14 \mathrm{~d}$ and $76.6 \%$ on $21 \mathrm{~d}$.

\section{Intraperitoneal glucose tolerance test (IPGTT)}

The result of IPGTT is shown in figure 2. Following intraperitoneal administration of glucose load (2 gm/ $\mathrm{kg}$ bw), MFE treated group showed significant reduction of FBG level (44\%) at $2 \mathrm{hr},(46.6 \%)$ at $4 \mathrm{hr}$ and metformin-treated group showed significant reduction of FBG level $(56.8 \%)$ at $2 \mathrm{hr}$ and $(60 \%)$ at $4 \mathrm{hr}$ when compared to the diabetic control group. Glibenclamide treated group showed very low reduction of FBG level $(15 \%)$ at $2 \mathrm{hr}$ and $(10 \%)$ at $4 \mathrm{hr}$ whereas insulin-treated group showed more pronounced glucose tolerance than all other groups with significant reduction of FBG level $(42.2 \%)$ at $5 \mathrm{hr},(60.9 \%)$ at 1 $\mathrm{hr},(84 \%)$ at $2 \mathrm{hr}$ and $(89.4 \%)$ at $4 \mathrm{hr}$ when compared with diabetic control group in the study.

\section{Biochemical analysis}

Serum and liver parameters

The result of lipid profile in different experimental groups is shown in table 1 . There were significant differences in the level of total cholesterol, triglyceride, HDL-C, LDL-C, and VLDL-C between the diabetic untreated group and normal untreated group in the study. Further, the total cholesterol, triglyceride, HDL-C, LDL-C and VLDL-C levels were found to be different in ascorbic acid treated group, as well as MFE, treated group when compared to the diabetic untreated group in the study.

As shown in Figure 3, the level of SGOT and SGPT were found to be significantly higher in the diabetic untreated group $(104.2 \pm 3.2$ and $58.7 \pm 2.1)$ in comparison to the normal 
untreated group $(50 \pm 4.2$ and $34.1 \pm 3.1)$. However, the level of SGOT and SGPT of ascorbic acid treated group (69.07 \pm 3.2 and $40.6 \pm 1.9)$ and MFE treated group $(70.7 \pm 1.2$ and $38.2 \pm 0.9)$ were significantly lower $(\mathrm{p}<0.001)$ than untreated diabetic group in the study.

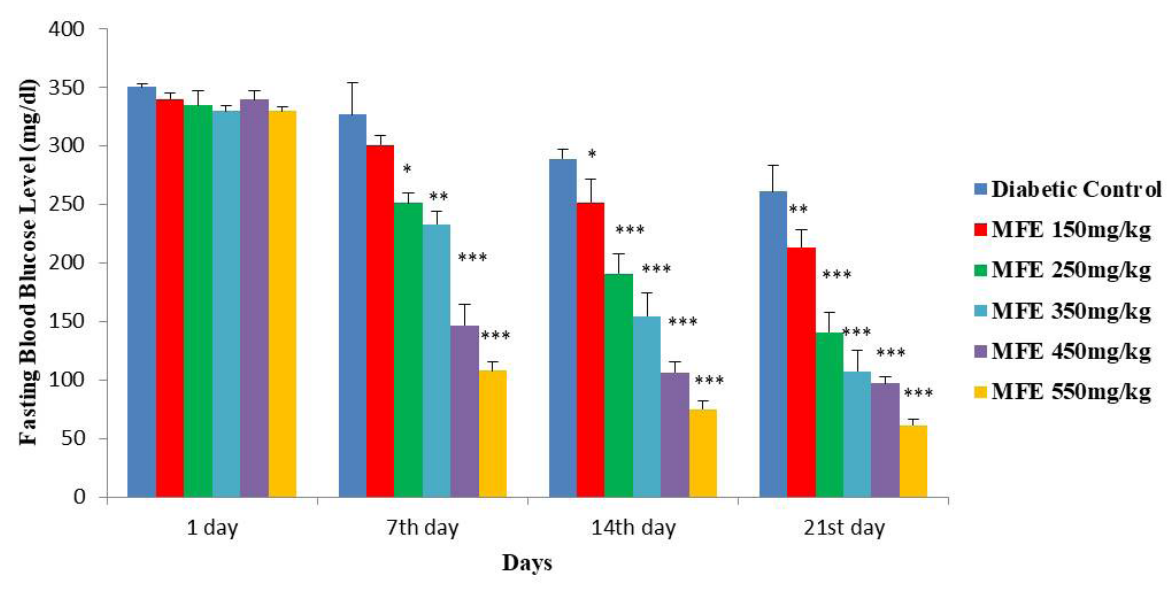

Fig. 1: Effects of MFE on diabetic mice showing changes of FBG level at the different time interval for different experimental groups (150-550 mg/kg bw dose). Values are expressed in Mean $\pm \mathrm{SEM} ; \mathrm{n}=6 .{ }^{*} \mathrm{p}<0.05,{ }^{* *} \mathrm{p}<0.01,{ }^{* *} \mathrm{p}<0.001$ versus diabetic control. (One-way ANOVA followed by tukey's post hoc test).

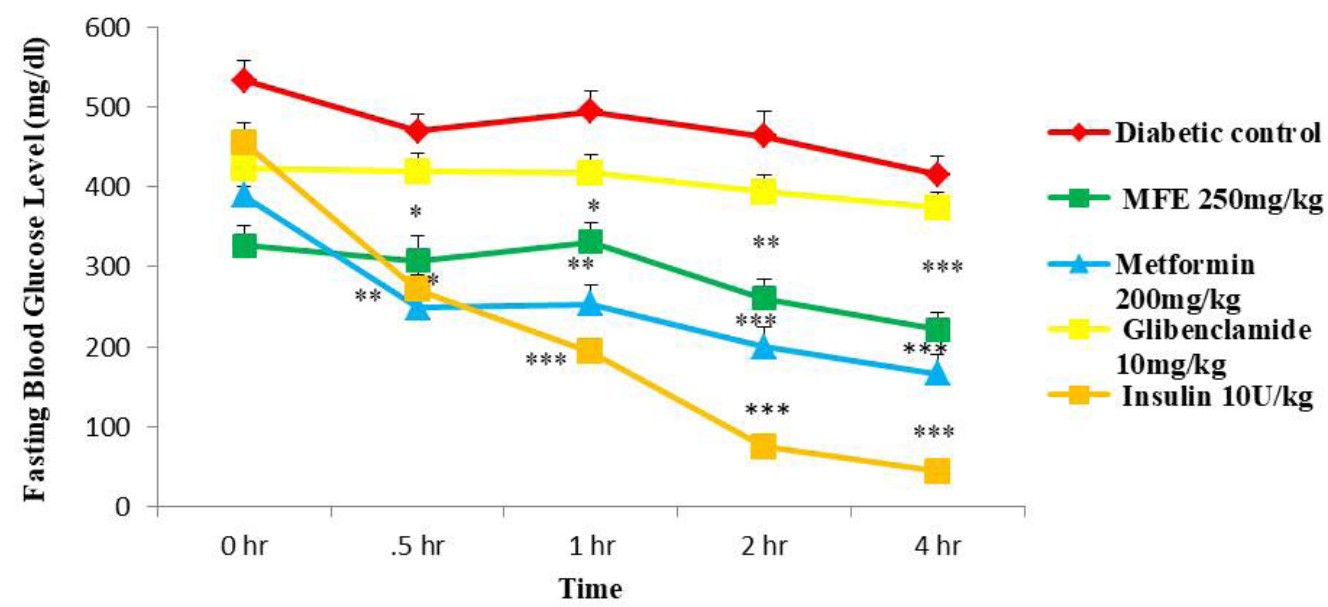

Fig. 2: IPGTT in different experimental groups administered with MFE and standard drugs (metformin, Glibenclamide, and insulin) in diabetic mice assayed at different time intervals. Values are expressed in Mean \pm SEM; $\mathrm{n}=6 .{ }^{*} \mathrm{p}<0.05,{ }^{*} \mathrm{p}<0.01,{ }^{* *} \mathrm{p}<0.001$ versus diabetic control. (One-way ANOVA followed by tukey's post hoc test).

Table 1: Effect of MFE on serum lipid profile in alloxan induced diabetic mice.

\begin{tabular}{|c|c|c|c|c|c|}
\hline Groups & Total cholesterol (mg/dl) & Triglyceride (mg/dl) & HDL (mg/dl) & LDL (mg/dl) & $\operatorname{VLDL}(\mathrm{mg} / \mathrm{dl})$ \\
\hline Normal untreated group & $118.0 \pm 0.53$ & $97.8 \pm 3.11$ & $75.5 \pm 1.1$ & $22.9 \pm 1.1$ & $19.5 \pm 0.62$ \\
\hline Diabetic untreated group & $176.7 \pm 2.9$ & $159.5 \pm 12.2$ & $49.9 \pm 1.9$ & $94.8 \pm 2.5$ & $31.9 \pm 3.3$ \\
\hline Ascorbic acid treated group & $115.5 \pm 3.59 * * *$ & $101.8 \pm 0.38^{* *}$ & $72.5 \pm 1.1^{* *}$ & $22.5 \pm 1.3 * * *$ & $20.3 \pm 0.07 * *$ \\
\hline MFE treated group & $123 \pm 5.2 * * *$ & $112.4 \pm 2.1^{*}$ & $68.2 \pm 0.91 * * *$ & $32.7 \pm 5.2 * * *$ & $22.4 \pm 0.42 *$ \\
\hline
\end{tabular}

Values are expressed in Mean $\pm \mathrm{SEM} ; \mathrm{n}=6 .{ }^{*} \mathrm{p}<0.05,{ }^{* *} \mathrm{p}<0.01,{ }^{* * *} \mathrm{p}<0.001$ versus diabetic control. (One-way ANOVA followed by tukey’s post hoc test).

\section{Antioxidant enzyme assays}

SOD (CuZn-SOD and Mn-SOD), CAT and GR activities in liver tissue of the experimental group are shown in table 2 . The SOD, CAT and GR activities were significantly reduced in the diabetic untreated group. However, ascorbic acid treated diabetic group and MFE treated diabetic group showed a significant increase in antioxidant activity with increased in SOD, CAT and GR activities in comparison to the diabetic control group in the study. 


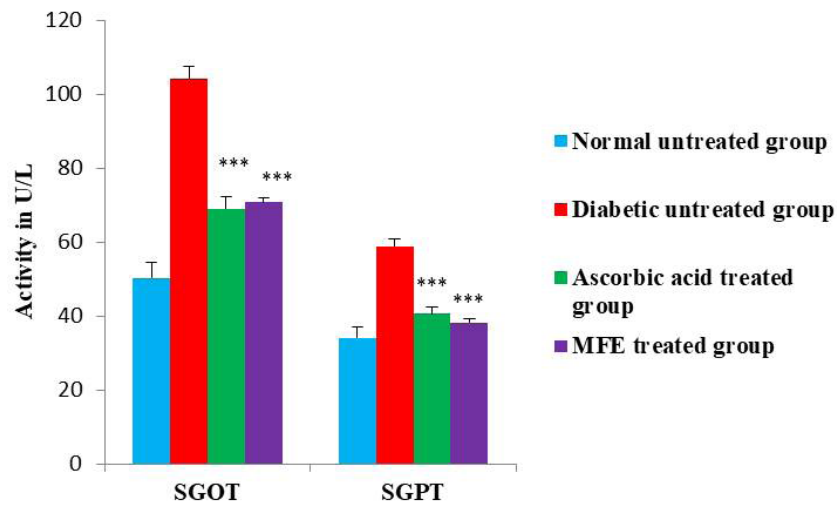

Fig. 3: Mean activity of hepatic marker enzymes (SGOT and SGPT) in the serum of Swiss albino mice. Values are expressed in Mean \pm SEM; $\mathrm{n}=6 . * * * \mathrm{p}<0.001$ versus diabetic control. (One-way ANOVA followed by tukey's post hoc test).
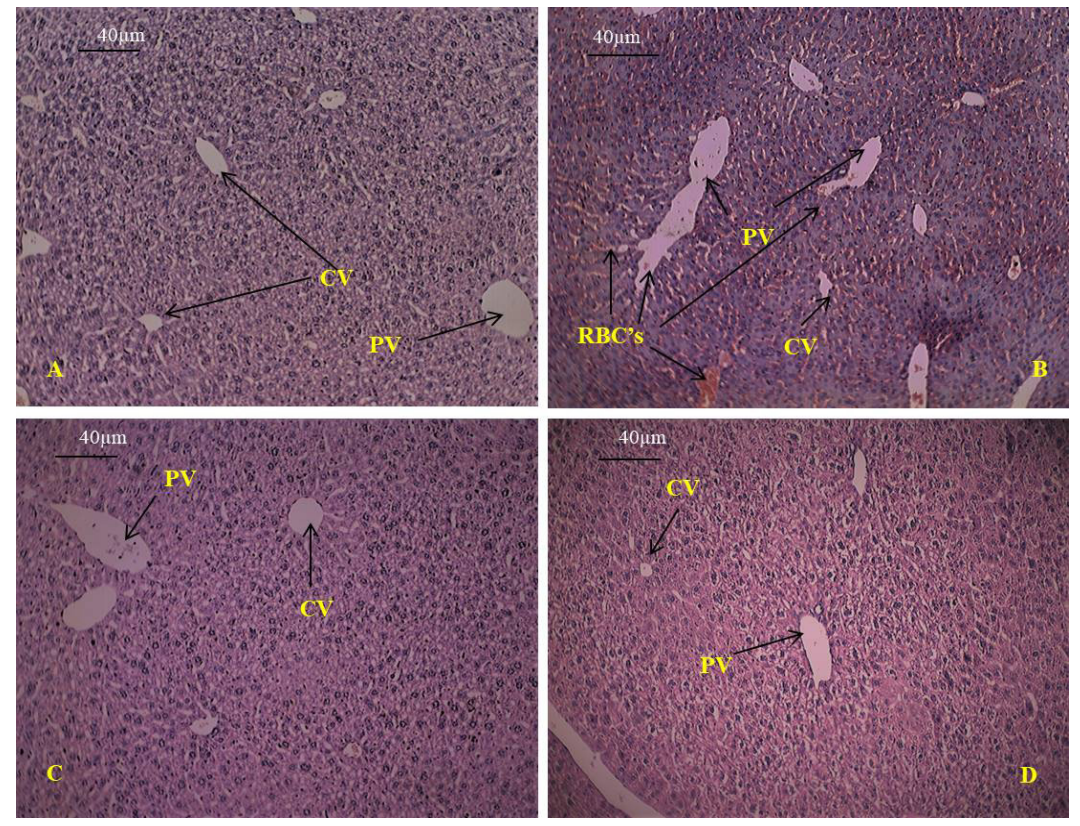

Fig. 4: Histological study of the liver (representative H\&E-stained). A1: normal mice, B: diabetic mice, C: ascorbic acid (50 mg/kg bw) treated diabetic mice, D: MFE $(250 \mathrm{mg} / \mathrm{kg} \mathrm{bw})$ treated diabetic mice. CV: central vein, PV: portal vein and RBCs: Red blood cells. All images are under 10X magnification.

\section{Histopathological examination}

As shown in figure 4, there was a loss of normal histological structure in the liver of diabetic mice with enlarged and distorted central and portal vein, sinusoidal dilation with red blood cells congestion was seen around central and portal vein when compared with normal mice. However, diabetic mice treated with ascorbic acid and MFE showed near normal histological structure with no central and portal vein enlargement or distortion. Moreover, sinusoidal dilation and red blood cells congestion around central and portal vein were also not seen.

\section{DISCUSSION}

The bioactivity of this crude extract is because of the presence of phenols, flavonoids, and tannins. Flavonoids are highly effective scavengers to oxidized molecules, including singlet oxygen, and various other free radicals implicated in several diseases (Bravo, 1998). Flavonoids suppress formation of reactive oxygen, chelate trace elements involved in the freeradical production, scavenge reactive species and up-regulate and protect antioxidant. Similarly, phenolic confer oxidative stress tolerance on plants (Agati, 2012). Acute toxicity study (LD50) was performed to examine the toxic effects when the extract is absorbed into the body via oral or intraperitoneal administration. The smaller the LD50 value, the more toxic would be the chemical (Turner, 1965). Induction of Type 1 diabetes by alloxan administration resulted in hyperglycemia in experimental groups. The doses below $150 \mathrm{mg} / \mathrm{kg}$ bw were found not to be effective to reduce the considerable blood glucose level and the doses above the $550 \mathrm{mg} / \mathrm{kg}$ bw showed severe hypoglycemic effect. The MFE exhibited a significant antihyperglycemic effect at the dose of $250 \mathrm{mg} / \mathrm{kg}$ bw. Hence, $250 \mathrm{mg} / \mathrm{kg}$ bw dose of MFE was considered to be the optimum dose for the study. In IPGTT, the MFE and other standard drugs showed a remarkable effect 
on blood glucose tolerance in diabetic mice however the most notable effect was observed in the case of insulin. The pattern of glucose clearance from blood in MFE administered group was quite similar to the drug metformin, which action is to enhance insulin action and absorption of glucose in peripheral tissues. The functional mechanism of drug glibenclamide used in the study is to stimulate pancreatic beta cells to release more insulin and inhibit glucagon secretion. Therefore, from the present study, the functional mechanism of MFE in lowering blood glucose level can be assumed as similar to the mechanism of metformin action.

Table 2: Mean activities of SOD, CAT, GR in MFE treated diabetic mice.

\begin{tabular}{|c|c|c|c|c|}
\hline \multirow[t]{2}{*}{ Groups } & \multicolumn{2}{|c|}{ Superoxide dismutase (Units/mg protein) } & \multirow{2}{*}{$\frac{\text { Catalase (Units/mg protein) }}{\text { CAT }}$} & \multirow{2}{*}{$\frac{\text { Glutathione reductase (Units/mg protein) }}{\text { GR }}$} \\
\hline & CuZn-SOD & Mn-SOD & & \\
\hline Normal untreated group & $5.6 \pm 0.06$ & $12.70 \pm 0.64$ & $2.7 \pm 0.16$ & $2.4 \pm 0.13$ \\
\hline Diabetic untreated group & $2.33 \pm 0.12$ & $8.19 \pm 0.17$ & $1.500 \pm 0.02$ & $1.463 \pm 0.11$ \\
\hline Ascorbic acid treated group & $3.99 \pm 0.22^{* * *}$ & $10.45 \pm 0.13^{* * *}$ & $2.205 \pm 0.13^{* *}$ & $2.237 \pm 0.039^{* * *}$ \\
\hline MFE treated group & $3.90 \pm 0.12^{* * *}$ & $10.64 \pm 0.21^{* * *}$ & $2.378 \pm 0.12^{* * *}$ & $2.121 \pm 0.12^{* *}$ \\
\hline
\end{tabular}

Values are expressed as Mean $\pm \mathrm{SEM} ; \mathrm{n}=6 .{ }^{* *} \mathrm{p}<0.01,{ }^{* * *} \mathrm{p}<0.001$ versus diabetic control (One-way ANOVA followed by tukey's post hoc test).

Total cholesterol, LDL-C, VLDL-C and triglyceride levels are known to increase during diabetes and triggers the risk of coronary heart disease and atherosclerosis in diabetic patients (Murray, 1993). In this study, treatment with MFE for 21 d remarkably reduced total cholesterol, LDL-C, VLDL-C and triglyceride followed by an increase in HDL-C levels which indicates that MFE has potent antihyperlipidemic activity. Serum aminotransferases levels are elevated when there is damaged to the liver, which can be considered to follow the progress during a diabetic condition in mice (Vigneri and Goldfine, 1987). MFE treated diabetic mice showed lower serum SGOT and SGPT levels than untreated diabetic mice.

SOD (Mn SOD and CuZn-SOD) present in mitochondria and cytosol is a first-line antioxidant enzyme that defends against reactive oxygen species. They eradicate superoxide anion to hydrogen peroxide (Evans, 2003). The hydrogen peroxide is further neutralized to water and oxygen by CAT enzyme (Johansen, 2005) which is also an antioxidant enzyme. GR antioxidant enzyme in cytoplasm functions through converting oxidized glutathione (GSSG) to reduce form (GSH) and helps in maintaining a reduced intracellular environment. In the present study, it was observed that MFE treatment restore and increase the activities of antioxidants enzymes when compared with untreated diabetic mice. Therefore, it could be said that MFE protects liver tissue from further oxidative stress under diabetic condition. From the histological study, it is evident that MFE has the ability to protect and restore tissues from the injury of oxidative stress induced by diabetes. It is also clear from the study that MFE is able to suppress oxidative stress by enhancing the antioxidative enzyme activities, thus allowing tissues to recover from further damage in diabetic mice.

\section{CONCLUSION}

The findings of the present study signify that MFE has both antihyperglycemic and antihyperlipidemic effects in alloxaninduced diabetic mice and treatment with MFE may provide beneficial effects against oxidative stress. However, the exact mechanism is yet to be elucidated and further investigation is underway.

\section{ACKNOWLEDGMENT}

The authors would like to thank the Department of Science and Technology (DST), New Delhi, India for providing
INSPIRE fellowship and also like to thank DRS programme, for providing infrastructural support to the Department of Biochemistry, NEHU, Shillong.

\section{CONFLICT OF INTERESTS}

There are no conflicts of interest.

\section{REFERENCES}

Aebi H. 1984. CAT in vitro. In: Methods Enzymol. New York: Academic Press.

Agati G, Azzarello E, Pollastri S, Tattini M. Flavonoids as antioxidants in plants: location and functional significance. Plant Sci, 2012; 196:67-76.

Bradford MM. A rapid and sensitive method for the quantitation of microgram quantities of protein utilizing the principle of protein-dye binding. Anal Biochem, 1976; 254(1-2):248-54.

Bravo L. Polyphenols: chemistry, dietary sources, metabolism and nutritional significance. Nutr Rev, 1998; 56:317-33.

Carlberg I, Mannervik B. Gutathione reductase. Methods in Enzymology, 1985; 113:484-90.

Evans JL, Goldfine ID, Maddux BA, Grodsky GM. Are oxidative stress-activated signaling pathways mediators of insulin resistance and \{beta\}-cell dysfunction? Diabetes, 2003; 52(1):1-8.

Friedewald WT, Levy RI, Fredrickson DS. Estimation of the concentration of low density lipoprotein in plasma without the use of preparative ultracentrifuge. Clin Chem, 1972; 18(6):499-502.

Ghosh MN. 2015. Fundamentals of experimental pharmacology. $6^{\text {th }}$ ed. Kolkata, Author self-publishers: Scientific Book Agency.

Harborne JB. 1998. Phytochemical methods. 3rd ed. London: Chapman \& Hall.

Jaiswal V. Culture and ethnobotany of Jaintia tribal community of Meghalaya, North-East India- A mini review. Indian J of Trad knowledge, 2010; 9(1):38-44.

Johansen JS, Harris AK, Rychly DJ, Ergula A. Oxidative stress and the use of antioxidants in diabetes: linking basic science to clinical practice. Cardiovasc Diabetol, 2005; 4(1):5-15.

Kashikar VS, Tejaswita K. Indigenous remedies for diabetes mellitus. Int J Pharm Pharm Sci, 2011; 3(3):22-29.

Kiernan JA. 1999. Histological and histochemical methods: Theory and practice. 3rd ed. Oxford: Butterworth Heinemann.

Marklund S, Marklund G. Involvement of the superoxide anion radical in the autoxidation of pyrogallol and a convenient assay for SOD. Eur J Biochem, 1974; 47(3):469-74.

Mathis D, Vence L, Benoist C. Review article beta-Cell death during progression to diabetes. Nature, 2001; 414:792-98.

Murray RK, Granner DK, Mayes PA. 1993. Catabolism of proteins and of amino acid nitrogen. In: Harper's Biochemistry. 23rd ed. London: Prentice-Hall International Limited. 
Saxena AK, Srivastava P, Kale RK, Baquer NZ. Impaired antioxidant status in diabetic rat liver: Effect of Vanadate. Biochem Pharmacol, 1993; 45(3):539-42.

Shaw JE, Sicree RA, Zimmet PZ. Global estimates of the prevalence of diabetes for 2010 and 2030. Diabetes Res Clin Pract, 2010; 87(1):4-14.

Syiem D, Gareth S, Khup PZ, Khongwir BS, Kharbuli B, Kayang H. Hypoglycemic effect of Potentilla fulgens L. in normal and alloxan-induced diabetic mice. J Ethnopharmacol, 2002; 83:55-61.

Syiem D, Khup PZ. Study of Traditionally Used Medicinal Plants Osbeckia chinensis Linn for Hypoglycemic and Antihyperglycemic Effects in mice. Pharm Biol, 2006; 44:613-18.

Syiem D, Gareth S, Khup PZ, Khongwir BS, Kharbuli B, Kayang H. Hypoglycemic effect of Potentilla fulgens L. in normal and alloxan-induced diabetic mice. J Ethnopharmacol, 2002; 83:55-56.

Taylor SI, Accili D, Imai Y. Insulin resistance or insulin deficiency: which is the primary cause of NIDDM? Diabetes, 1994; 43(6):735-40.
Turner R. 1965. Acute toxicity: The determination of LD50. In Screening Methods in Pharmacology. New York: Academic Press.

Vigneri R, Goldfine ID. Role of metformin in treatment of diabetes mellitus. Diabetes Care, 1987; 10(1):118-22.

Wani SA, Shah KW, Ahmad MA. Preliminary phytochemical investigation and thin layer chromatography of Rheum emodi. Int Res J Phar, 2012; 3(4):176-77.

Wild S, Roglic G, Green A, Sicree R, King H. Global prevalence of diabetes estimates for the year 2000 and projections for 2030. Diabetes Care, 2004; 27(5):1047-53.

\section{How to cite this article:}

Bora J, Sahariah P, Patar AK, Syiem D, Bhan S. Attenuation of diabetic hepatopathy in alloxan-induced diabetic mice by methanolic flower extract of Phlogacanthus thyrsiflorus Nees. J App Pharm Sci, 2018; 2018; 8(07): 114-120. 